\title{
Two to Three Times Weekly
}

National Cancer Institute

\section{Source}

National Cancer Institute. Two to Three Times Weekly. NCI Thesaurus. Code C118854.

Scheduled or occurring at a frequency of two or three times per week. 